\title{
6. GEOCHEMICAL STRATIFICATION IN THE UPPER MANTLE: EVIDENCE FROM LEG 115 BASALTS IN THE INDIAN OCEAN ${ }^{1}$
}

\author{
Yoshiyuki Tatsumi ${ }^{2}$ and Susumu Nohda ${ }^{3}$
}

\begin{abstract}
Melting-phase relations at high pressures and $\mathrm{Sr}-\mathrm{Nd}$ isotopic compositions are reported for basalts collected from the western Indian Ocean during Ocean Drilling Program Leg 115. Based on the concentrations of high-field-strength elements, we have subdivided the basalts into eight groups. A tholeitic primary magma estimated using an olivine maximum fractionation model is representative of depleted lavas. This melt is in equilibrium with lherzolite minerals at 1.3 $\mathrm{GPa}$ and $1330^{\circ} \mathrm{C}$ under dry conditions. Also, an alkaline primary magma, representative of enriched lavas, is not saturated with orthopyroxene under dry conditions, but it is saturated with lherzolite minerals under $\mathrm{CO}_{2}$-saturated conditions at $1.7 \mathrm{GPa}$ and $1350^{\circ} \mathrm{C}$. These results imply that the tholeiitic magmas were segregated from mantle diapirs at shallower levels than the alkaline magmas. The highest ${ }^{143} \mathrm{Nd} /{ }^{144} \mathrm{Nd}$ value is obtained for the most depleted tholeiitic basalts, and the lowest value corresponds to the enriched alkaline basalt. The $\mathrm{Sr}$ isotopes of the basalts range from 0.70378 to 0.70449 and are inversely correlated with the $\mathrm{Nd}$ isotopic values. The present experimental and geochemical data suggest that depleted mantle material is underlain by the enriched material in the upper mantle beneath the region.
\end{abstract}

\section{INTRODUCTION}

The existence of heterogeneities in Earth's mantle is now well established in terms of petrography (Boyd and Nixon, 1975), mineralogy (Ringwood, 1970), geochemistry (Gast, 1968), and seismology (Dziewonski et al., 1977). These heterogeneities have been recognized vertically as well as laterally. It is generally agreed that the mantle is composed of at least two distinct geochemical components: an incompatible-element-depleted material that is the main source for Mid-Ocean Ridge basalts (MORB; DePaolo and Wasserburg, 1976, 1979), and a less depleted or fertile or enriched material, including recycled oceanic crust, subcontinental mantle, continental crust, and bulk silicate earth (White, 1985; Zindler and Hart, 1986; Allégre et al., 1987). Although many models advocating geochemical stratification in the mantle have been proposed (Silver et al., 1988; Wyllie, 1988), the relative distribution of depleted and fertile sources is still a topic for debate. DePaolo and Wasserburg (1976) proposed a twolayer mantle model, in which the upper mantle is more depleted in incompatible elements through the process of continental crust formation. On the other hand, Anderson (1982) insisted that the uppermost mantle is enriched by fluid phases derived from deeper and less enriched mantle.

This paper will present melting-phase relations at high pressures and $\mathrm{Sr}-\mathrm{Nd}$ isotope compositions of basalts collected from the western Indian Ocean during Ocean Drilling Program (ODP) Leg 115 . We will also discuss the pressure-temperature (P-T) conditions of magma generation and examine geochemical stratification in the upper mantle beneath the region.

\section{SAMPLES}

Basalts were recovered from Sites $706,707,713$, and 715 (Fig. 1) located on the aseismic ridges in the western Indian Ocean. The ridge is presently interpreted to be a hotspot track that extends from now-active Réunion through Mauritius, the Mascarene Plateau, and the Chagos-Maldives-Laccadive plateaus

${ }^{1}$ Duncan, R. A., Backman, J., Peterson, L. C., et al., 1990. Proc. ODP, Sci. Results, 115: College Station, TX (Ocean Drilling Program).

2 Department of Geology and Mineralogy, Kyoto University, Kyoto 606, Japan.

${ }^{3}$ Kyoto Sangyo University, Kamigamo, Kyoto 603, Japan. and ends at the Deccan Traps (Morgan, 1981; Duncan, 1981). Basalts can be clearly divided into eight groups based on concentrations of $\mathrm{Zr}$ as representative of high-field-strength elements and $\mathrm{Ba}$ concentrations of the large-ion-lithophile elements (Fig. 2). Basalts from one site are composed of two geochemical groups; for example, at Site 706, basalts can be divided into an enriched group (706-E) and a depleted group (706-D). The 706-E basalts are strongly enriched in incompatible elements and have chemical characteristics close to alkaline basalts and their derivative rocks from Réunion (Fisk et al., 1988) and Mauritius (Baxter, 1975), as shown in Figure 3. The large difference in the concentration of incompatible elements at a constant $\mathrm{MgO}$ (e.g., 706-E vs. 706-D; Fig. 2) clearly indicates that the difference in geochemical characteristics cannot be attained by variations in the degree of partial melting of an identical source material or of simple fractional crystallization from a single primary magma composition.

The 706-E basalts contain titaniferous augite, suggesting that these rocks are rather alkaline. This is consistent with the observed enrichment of incompatible elements. Also, basalts from Réunion and Mauritius, which form a single differentiation trend with 706-E (Fig. 3), occupy a boundary between tholeiitic and alkaline basalts (Fisk et al., 1988). On the other hand, 707-D basalts show no petrographic signature of alkaline rocks and are depleted in incompatible elements; they undoubtedly belong to the tholeiite series. Experimental petrology (Kushiro, 1969; Jaques and Green, 1980; Takahashi and Kushiro, 1983) has suggested that alkaline basalt magmas are produced at higher pressures and lower degrees of partial melting than tholeiitic basalt magmas. Basalts other than the 706-E and 707-D groups, which show intermediate chemical characteristics in terms of concentration of incompatible elements, could be initially produced at intermediate pressures between those for 706-E and 707-D parental melts. Thus, we have selected two end-member samples, 706-E and 707-D, for melting experiments at high pressures.

Melting-phase relations of basalts can provide strong constraints on the estimation of P-T conditions for magma segregation from the source material or the mantle diapir (Fujii and Kushiro, 1977; Tatsumi et al., 1983). However, to obtain realistic information about magma generation, we have to select the starting materials carefully and use compositions that are likely to be in equilibrium with mantle minerals. Generally, magmas formed 


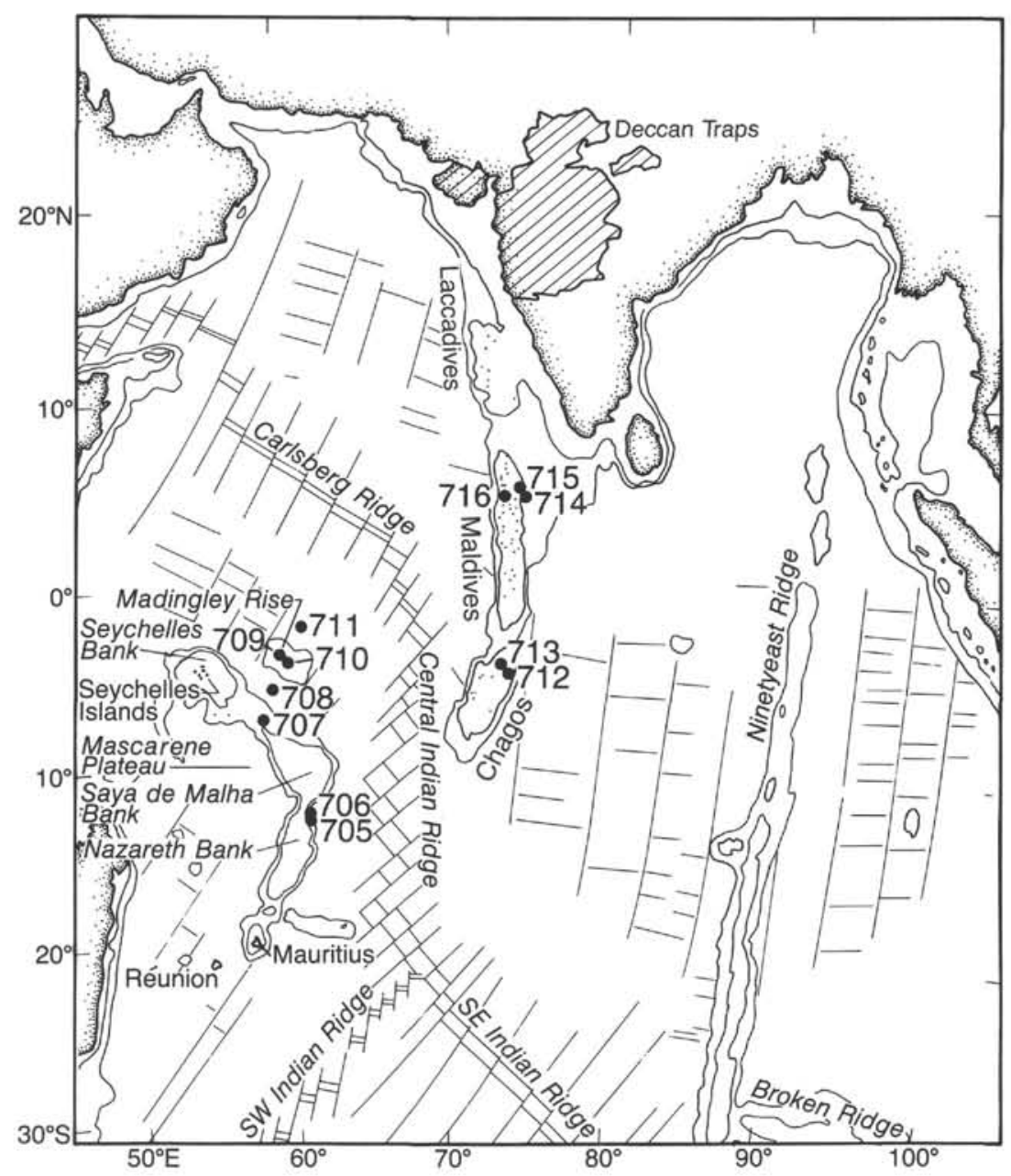

Figure 1. Bathymetric features of the central Indian Ocean with 2- and 4-km depth contours. Numbers indicate sites drilled during Leg 115; basement rocks were recovered at Sites 706, 707, 713, and 715 .

in the upper mantle have experienced shallow-level fractionation of basaltic minerals and do not represent primary compositions. At the early stage of fractional crystallization, the differentiation process is governed by the separation of olivine from the magma. Therefore, we can estimate the primary magma composition for primitive or magnesian rocks based on the olivine maximum fractional crystallization model (Tatsumi and Ishizaka, 1982; Tatsumi et al., 1983).

We have chosen the two most primitive rocks (i.e., low in FeO*/MgO; Table 1) from 707-D basalts and calculated the primary magma compositions that could be in equilibrium with mantle olivine of $\mathrm{Fo}_{90}$ composition. Assumptions other than the composition of mantle olivine are the same as those in Tatsumi et al. (1983): (1) the olivine maximum fractionation; (2) $\left(\mathrm{Fe}^{2+}\right.$ / $\left.\mathrm{Fe}^{2+}+\mathrm{Fe}^{3+}\right)_{\text {magma }}=0.9$; and (3) the $\mathrm{Fe}-\mathrm{Mg}$ exchange partition coefficient between olivine and liquid is 0.3 (Roeder and Emslie, 1970). The average of the two estimated magmas is taken as a primary magma for 707-D basalts (Table 1). Although plagioclase is a dominant phenocryst phase in 707-D basalts, the chemical trend of $\mathrm{Al}_{2} \mathrm{O}_{3}$ vs. $\mathrm{MgO}$ in Figure 3 shows the increase of $\mathrm{Al}_{2} \mathrm{O}_{3}$ with decreasing $\mathrm{MgO}$ in magnesian rocks, indicating no significant fractionation of plagioclase in those magmas.

Rocks belonging to the 706-E chemical group are poor in $\mathrm{MgO}$ (Figs. 2 and 3 ) and should have experienced severe fractionation of mafic minerals, probably including clinopyroxene.
Thus, the compositions of primary magmas for 706-E rocks cannot be estimated by the above olivine maximum fractionation model. It is probable that rocks of 706-E have undergone similar differentiation processes as those taking place in the Réunion and Mauritius magmas, because compositions of 706-E rocks are plotted well within the differentiation trend for Réunion (Fig. 3) and also Mauritius rocks (cf. Baxter, 1975). The composition of the RE464 basalt (Fisk et al., 1988), which has the lowest $\mathrm{FeO}^{*} / \mathrm{MgO}$ ratios among the Réunion noncumulate basalts, is taken as a primary magma for 706-E basalts. The $\mathrm{FeO}^{*} / \mathrm{MgO}$ ratio of the RE464 basalt is slightly higher than that of the estimated primary magma for 707-D (Table 1), which must affect the phase relations of these basalts. This problem will be discussed below.

\section{EXPERIMENTAL METHODS}

\section{Melting Experiments at High Pressures}

Starting materials of primary magma compositions listed in Table 1 were prepared from analytical reagent grade chemicals, ground under acetone, and heated at $900^{\circ} \mathrm{C}$ for $4 \mathrm{hr}$. They were fused at $1400^{\circ} \mathrm{C}$ in air for $10 \mathrm{~min}$ within an iron-saturated $\mathrm{Pt}$ crucible and then quenched. The glass was again melted at 1.0 $\mathrm{GPa}$ and $1450^{\circ} \mathrm{C}$ within a graphite capsule for $1 \mathrm{hr}$. The quenched glass was ground and dried at $110^{\circ} \mathrm{C}$ for 4 days. 


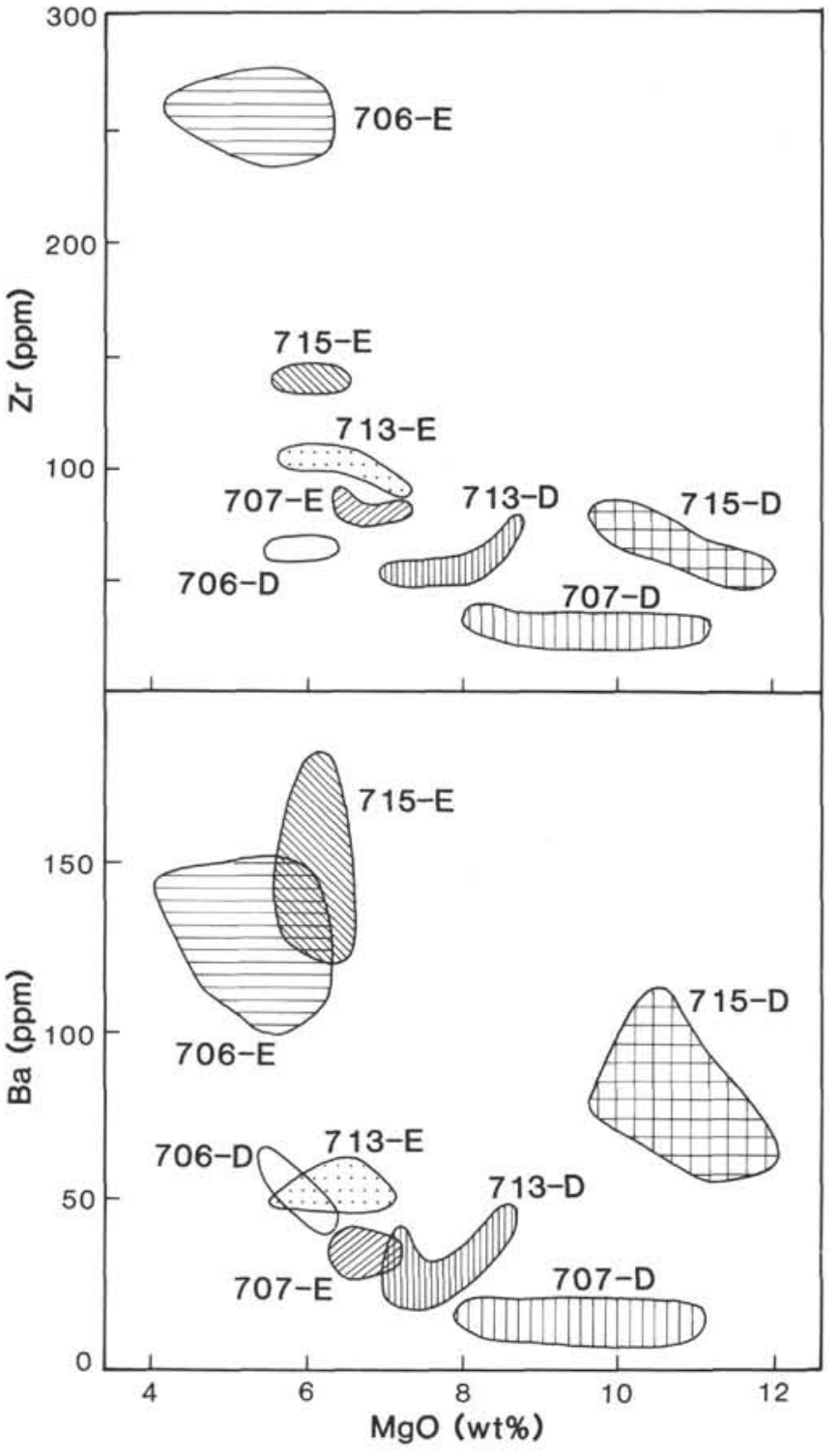

Figure 2. $\mathrm{MgO}-\mathrm{Zr}$ and $\mathrm{MgO}-\mathrm{Ba}$ variation diagram for $\mathrm{Leg} 115$ basement rocks. The basaltic rocks can be divided into eight geochemical groups, based in particular on the differences in $\mathrm{Zr}$ content.

All high-pressure experiments were carried out in a solid-media, high-pressure apparatus (Boyd and England, 1960) at Kyoto University, using the piston-out experimental technique (Boyd et al., 1962). The furnace assembly is composed of talc, pyrex glass, a graphite heater, crushable alumina plugs, and annealed $\mathrm{MgO}$ powder.

Under anhydrous and $\mathrm{CO}_{2}$-absent conditions, the starting glass was set in an inner graphite capsule with an outer Pt capsule; under $\mathrm{CO}_{2}$-saturated conditions, $\mathrm{Pt}$ capsules were arc welded at both ends and used as sample containers. A portion of the iron in a starting material was lost during melting experiments using $\mathrm{Pt}$ capsules. However, time studies with run durations up to $5 \mathrm{hr}$ have indicated that phase relations are not affected by the iron loss during $5 \mathrm{hr}$. We added $\mathrm{Ag}_{2} \mathrm{C}_{2} \mathrm{O}_{4}$ so that the total $\mathrm{CO}_{2}$ content of the charge was $15-20 \mathrm{wt} \%$. Capsules containing $\mathrm{CO}_{2}$ were weighed before and after welding to ensure that no volatile was lost.

Temperatures measured with $\mathrm{Pt}-\mathrm{Pt}_{87} \mathrm{Rh}_{13}$ thermocouples were precise to within $2^{\circ}-3^{\circ} \mathrm{C}$ and have not been corrected for the
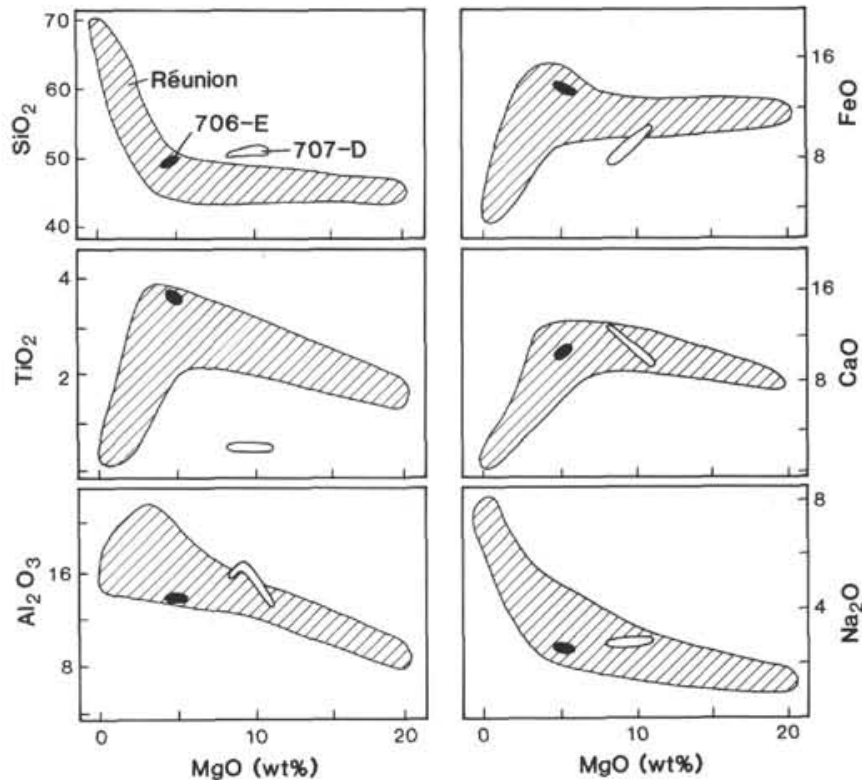

Figure 3. $\mathrm{MgO}$-oxide variation diagram for Réunion volcanic rocks (Fisk et al., 1988) and rocks of geochemical group 707-D and 706-E (see Fig. 1). Basalts of 706-E are plotted well within the differentiation trend for Réunion rocks.

Table 1. Chemical compositions of magnesian basalts and estimated primary magmas.

\begin{tabular}{|c|c|c|c|c|c|c|c|c|}
\hline & 1 & 2 & 3 & 4 & 5 & 6 & 7 & 8 \\
\hline $\mathrm{SiO}_{2}$ & 50.44 & 50.34 & & 46.29 & & 48.49 & 48.58 & 48.50 \\
\hline $\mathrm{TiO}_{2}$ & 0.66 & 0.58 & & 2.34 & & 0.98 & 0.99 & 1.17 \\
\hline $\mathrm{Al}_{2} \mathrm{O}_{3}$ & 16.39 & 15.90 & & 12.40 & & 15.22 & 15.09 & 15.77 \\
\hline $\mathrm{FeO}^{*}$ & 9.26 & 9.42 & & 11.80 & & 10.68 & 10.72 & 10.65 \\
\hline $\mathrm{MnO}$ & 0.10 & 0.13 & & 0.18 & & 0.18 & 0.18 & 0.16 \\
\hline $\mathrm{MgO}$ & 8.81 & 9.03 & & 13.28 & & 11.92 & 11.05 & 11.00 \\
\hline $\mathrm{CaO}$ & 12.37 & 12.64 & & 10.95 & & 10.73 & 11.73 & 10.67 \\
\hline $\mathrm{Na}_{2} \mathrm{O}$ & 1.90 & 1.88 & & 2.07 & & 1.51 & 1.59 & 1.70 \\
\hline $\mathrm{K}_{2} \mathrm{O}$ & 0.05 & 0.05 & & 0.42 & & 0.18 & 0.26 & 0.26 \\
\hline $\mathrm{P}_{2} \mathrm{O}_{5}$ & 0.03 & 0.02 & & 0.27 & & 0.11 & 0.11 & 0.11 \\
\hline $\mathrm{FeO}^{*} / \mathrm{MgO}$ & 1.05 & 1.04 & & 0.89 & & 0.90 & 0.97 & 0.97 \\
\hline $\mathrm{SiO}_{2}$ & 49.66 & 49.58 & 49.61 & & 46.43 & 47.96 & 47.48 & 47.99 \\
\hline $\mathrm{TiO}_{2}$ & 0.59 & 0.52 & 0.56 & & 2.35 & 0.91 & 0.89 & 1.05 \\
\hline $\mathrm{Al}_{2} \mathrm{O}_{3}$ & 14.59 & 14.17 & 14.38 & & 12.43 & 14.12 & 13.56 & 14.20 \\
\hline $\mathrm{FeO}^{*}$ & 9.43 & 9.57 & 9.50 & & 11.83 & 10.67 & 10.69 & 11.00 \\
\hline $\mathrm{MnO}$ & 0.09 & 0.12 & 0.11 & & 0.18 & 0.17 & 0.16 & 0.14 \\
\hline $\mathrm{MgO}$ & 12.88 & 13.05 & 12.97 & & 13.31 & 14.56 & 14.61 & 14.50 \\
\hline $\mathrm{CaO}$ & 11.01 & 11.26 & 11.14 & & 10.98 & 9.95 & 10.54 & 9.61 \\
\hline $\mathrm{Na}_{2} \mathrm{O}$ & 1.69 & 1.68 & 1.69 & & 2.07 & 1.40 & 1.43 & 1.53 \\
\hline $\mathrm{K}_{2} \mathrm{O}$ & 0.04 & 0.04 & 0.04 & & 0.42 & 0.17 & 0.23 & 0.46 \\
\hline $\mathrm{P}_{2} \mathrm{O}_{5}$ & 0.03 & 0.02 & & & & 0.10 & 0.10 & 0.11 \\
\hline $\mathrm{FeO}^{*} / \mathrm{MgO}$ & 0.73 & 0.73 & 0.73 & & 0.89 & 0.73 & 0.73 & 0.73 \\
\hline
\end{tabular}

Note: Col. 1 = Sample 115-707C-22R-1, 24-27 cm; Col. 2 = Sample 115-707C-23R-1, $123-127 \mathrm{~cm} ; \mathrm{Col} .3$ = primary magma for chemical group 707-D (starting material); Col. $4=$ RE464 (Fisk et al., 1988); Col. 5 = primary magma for chemical group 706-E (starting material); Col. $6=$ Sample 115-715C-25R-3, $25-34 \mathrm{~cm}$; Col. 7 = Sample 115-715C-25R-6, 38-42 cm; Col. 8 = Sample 115-715C-30R-6. $0-9 \mathrm{~cm}$.

pressure effect on thermocouple electromotive force. The runs were quenched by turning off the power to the furnace. Quenched products were crushed and examined under microscope.

\section{Isotope Analysis}

The Sr-Nd isotopic compositions were determined for seven distinct chemical groups excepting 715-E. Splits of the powdered samples weighing about $100 \mathrm{mg}$ were decomposed by HF$\mathrm{HClO}_{4}$ mixture in Teflon beakers. The $\mathrm{Sr}$ was eluted first through a large cation-exchange column ( $\phi 10 \mathrm{~mm}, 15-\mathrm{ml}$ resin volume) 
using $2 \mathrm{~N}-\mathrm{HCl}$. The light rare earth elements (REE) were then collected using $4 \mathrm{~N}-\mathrm{HCl}$ as an eluent. Further purification of the REE was carried out with small cation-exchange columns ( $\phi 4$ $\times \mathrm{H} 40 \mathrm{~mm}$ ). Then, the REE were loaded onto a micro column $(\phi 2 \times \mathrm{H} 300 \mathrm{~mm})$ and treated with a $0.2-\mathrm{M}$ meteolactic acid solution that was adjusted with ammonium hydroxide to a $\mathrm{pH}$ $=4.60$. The $\mathrm{Nd}$ obtained from this final column exchange was loaded on Ta filament and measured as the metal species by a double filament system with a Finnegan MAT 261E mass-spectrometer at Kyoto Sangyo University.

The ${ }^{143} \mathrm{Nd} /{ }^{144} \mathrm{Nd}$ ratios measured were normalized to a ${ }^{146} \mathrm{Nd} /$ ${ }^{144} \mathrm{Nd}$ ratio $=0.7219$, and trace contributions from ${ }^{144} \mathrm{Sm}$ were checked by monitoring ${ }^{147} \mathrm{Sm}$. The average value of the ${ }^{143} \mathrm{Nd} /$ ${ }^{144} \mathrm{Nd}$ ratio for the La Jolla standard during the study was $0.511855 \pm 8(N=16)$. Strontium was measured on a Ta single filament. We obtained ${ }^{87} \mathrm{Sr} /{ }^{86} \mathrm{Sr}$ ratios of $0.704990 \pm 3(N=4)$ for BCR-1, $0.710223 \pm 12(N=4)$ for NBS-987 Sr, and $0.707990 \pm 6(N=5)$ for Eimer \& Amend $\mathrm{SrCO}_{3}$. In the present study, the analyzed samples were not leached by $\mathrm{HCl}$. Accordingly, the present $\mathrm{Sr}$ isotopic compositions are probably elevated because of seawater contamination during emplacement of the lavas.

\section{RESULTS}

Results of high-pressure melting experiments are listed in Table 2 and plotted on P-T diagrams (Fig. 4). The 707-D primary basalt crystallized olivine as a liquidus phase at pressures below $1.3 \mathrm{GPa}$ and clinopyroxene plus orthopyroxene at higher pressures. These data suggest that the anhydrous 707-D basalt is multiply-saturated with lherzolite minerals at pressures of about $1.3 \mathrm{GPa}$ and temperatures of about $1330^{\circ} \mathrm{C}$. The anhydrous RE464 basalt, which is a possible primary magma for the 706-D basalts, is not saturated with orthopyroxene under any P-T conditions in the dry, $\mathrm{CO}_{2}$-absent experiments; on the other hand, lherzolite minerals appear simultaneously on the liquidus under $\mathrm{CO}_{2}$-saturated conditions. The P-T conditions for the multiple saturation are $1.7 \mathrm{GPa}$ and $1350^{\circ} \mathrm{C}$. Fisk et al. (1988) conducted melting experiments on anhydrous RE464 basalts and reported phase relations at pressures below $2.0 \mathrm{GPa}$ and temperatures up to $1400^{\circ} \mathrm{C}$. Our experimental results under dry conditions are
Table 2. Results of melting experiments.

\begin{tabular}{lccc}
\hline $\begin{array}{c}\text { Pressure } \\
(\mathrm{GPa})\end{array}$ & $\begin{array}{c}\text { Temperature } \\
\left({ }^{\circ} \mathrm{C}\right)\end{array}$ & $\begin{array}{c}\text { Time } \\
(\mathrm{hr})\end{array}$ & Results \\
\hline
\end{tabular}

\begin{tabular}{ccll}
\hline \multicolumn{2}{c}{ Chemical group 707-D: } \\
\multicolumn{3}{l}{$l$} \\
1.0 & 1315 & 2.0 & $\mathrm{ol}+\mathrm{cpx}+\mathrm{L}$ \\
1.0 & 1325 & 2.0 & $\mathrm{ol}+\mathrm{L}$ \\
1.0 & 1335 & 2.0 & $\mathrm{~L}$ \\
1.1 & 1310 & 2.0 & $\mathrm{ol}+\mathrm{cpx}+\mathrm{opx}+\mathrm{L}$ \\
1.1 & 1320 & 2.0 & $\mathrm{ol}+\mathrm{cpx}+\mathrm{L}$ \\
1.2 & 1320 & 1.5 & $\mathrm{ol}+\mathrm{cpx}+\mathrm{opx}+\mathrm{L}$ \\
1.3 & 1320 & 1.5 & $\mathrm{ol}+\mathrm{cpx}+\mathrm{opx}+\mathrm{L}$ \\
1.3 & 1335 & 1.5 & $\mathrm{~L}$ \\
1.3 & 1350 & 1.5 & $\mathrm{~L}$ \\
1.4 & 1320 & 1.5 & $\mathrm{cpx}+\mathrm{opx}+\mathrm{L}$ \\
1.6 & 1340 & 1.5 & $\mathrm{cpx}+\mathrm{opx}+\mathrm{L}$ \\
1.6 & 1350 & 1.5 & $\mathrm{~L}$ \\
\end{tabular}

Chemical group 706-E (RE464) "dry":

$\begin{array}{llll}1.7 & 1400 & 1.5 & \text { ol }+\mathrm{L} \\ 1.8 & 1400 & 1.5 & \mathrm{ol}+\mathrm{L} \\ 1.8 & 1410 & 1.5 & \mathrm{ol}+\mathrm{L} \\ 1.9 & 1390 & 1.5 & \mathrm{ol}+\mathrm{cpx}+\mathrm{L} \\ 1.9 & 1400 & 1.5 & \mathrm{ol}+\mathrm{cpx}+\mathrm{L} \\ 2.0 & 1390 & 1.5 & \mathrm{cpx}+\mathrm{L} \\ 2.0 & 1410 & 1.5 & \mathrm{cpx}+\mathrm{L} \\ 2.0 & 1420 & 1.5 & \mathrm{~L}\end{array}$

Chemical group 706-E (RE464) " $\mathrm{CO}_{2}$-saturated":

\begin{tabular}{llll}
1.5 & 1330 & 1.5 & ol $+\mathrm{cpx}+\mathrm{L}+\mathrm{V}$ \\
1.5 & 1340 & 1.5 & ol $+\mathrm{L}+\mathrm{V}$ \\
1.5 & 1350 & 1.5 & $\mathrm{~L}+\mathrm{V}$ \\
1.6 & 1330 & 1.5 & ol $+\mathrm{cpx}+\mathrm{L}+\mathrm{V}$ \\
1.7 & 1330 & 1.5 & ol $+\mathrm{cpx}+\mathrm{opx}+\mathrm{L}+\mathrm{V}$ \\
1.7 & 1330 & 5.0 & ol $+\mathrm{cpx}+\mathrm{opx}+\mathrm{L}+\mathrm{V}$ \\
1.7 & 1340 & 1.5 & ol $+\mathrm{cpx}+\mathrm{opx}+\mathrm{L}+\mathrm{V}$ \\
1.7 & 1350 & 1.5 & $\mathrm{~L}+\mathrm{V}$ \\
1.8 & 1330 & 1.5 & $\mathrm{cpx}+\mathrm{opx}+\mathrm{L}+\mathrm{V}$ \\
1.8 & 1350 & 1.5 & $\mathrm{cpx}+\mathrm{opx}+\mathrm{L}+\mathrm{V}$ \\
1.8 & 1360 & 1.5 & $\mathrm{~L}+\mathrm{V}$ \\
1.9 & 1360 & 1.5 & $\mathrm{~L}+\mathrm{V}$ \\
\hline
\end{tabular}

Note: ol = olivine, $\mathrm{cpx}=$ clinopyroxene, opx = orthopyroxene, $\mathrm{L}=$ liquid (glass), and $\mathrm{V}=$ quenched vapor.
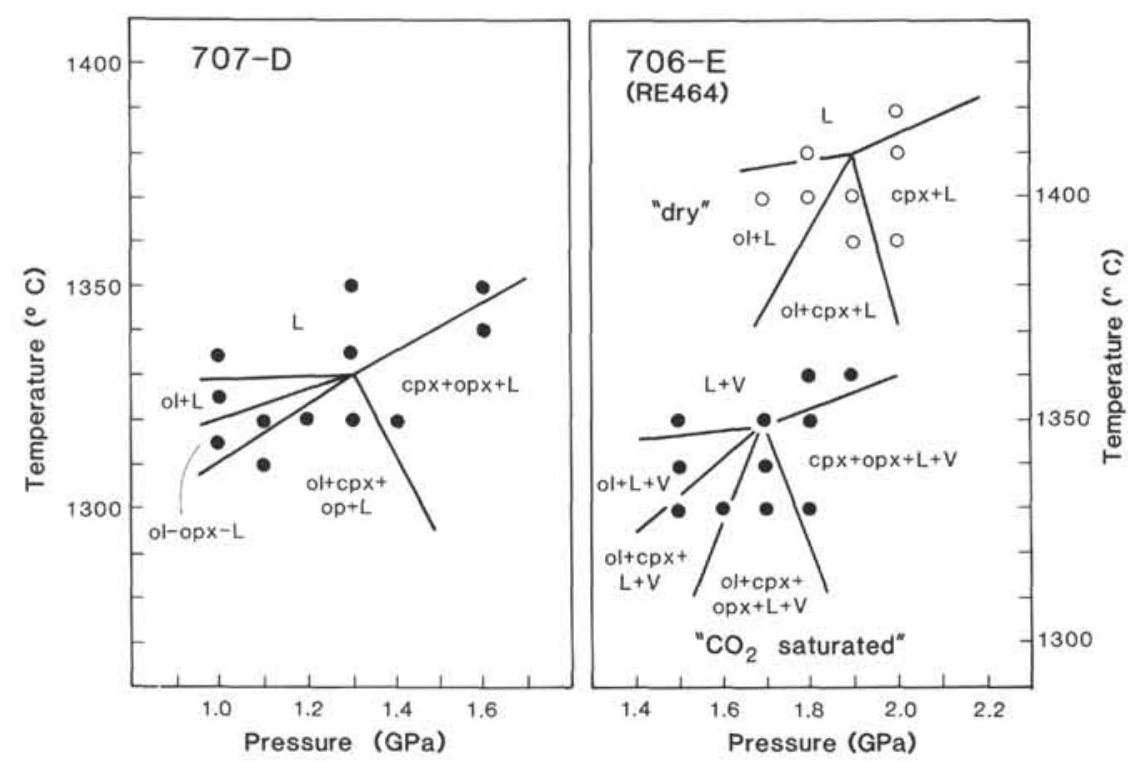

Figure 4. Melting-phase relations for two possible primary magmas. Abbreviations are the same as given in Table 2. 
consistent with those obtained by Fisk et al. (1988), although they did not determine the multiple saturation point of olivine and clinopyroxene on the liquidus.

The results of our isotopic analyses are listed in Table 3. The $\mathrm{Nd}$ and $\mathrm{Sr}$ isotope data are plotted on an ordinary correlation diagram (Fig. 5) together with published data for Réunion samples (Fisk et al., 1988) and normalized MORB (N-MORB) from the central Indian Ocean spreading ridge (Mahoney et al., 1989). Taking into account the observation that basalts obtained at Sites 706, 713, and possibly 707 were subaqueous lava flows (Backman, Duncan, et al., 1988), the Sr-isotope compositions of the present samples may have been changed through the process of seawater interaction with the basalts. All $\mathrm{Sr}$ isotopic ratios are likely elevated over initial primary values.

The Nd isotope composition for 707-D basalts is well within the compositional range reported for N-MORB; 706-E shows the most enriched isotope signature among the present samples. The Nd isotope compositions of the chemical groups 706-D, 707-E, 713-D, 713-E, and 715-D show intermediate Nd isotope compositions between 706-E and 707-D, which is quite consistent with chemical grouping based on the concentration of incompatible elements. Although Réunion basalts show similar concentrations of incompatible trace elements as 706-E basalts, the former are slightly enriched in terms of $\mathrm{Sr}-\mathrm{Nd}$ isotope compositions (Fig. 5).

\section{DISCUSSION}

\section{Pressure-Temperature Conditions of Magma Generation}

The basalt melt with the composition of a primary magma for the 707-D chemical group is in equilibrium with lherzolite minerals at $1.3 \mathrm{GPa}$ and $1330^{\circ} \mathrm{C}$, suggesting the possibility that the primary magma was separated from the upper mantle under the above P-T conditions, leaving lherzolite as a residual material. It is well established that the existence of such volatiles as $\mathrm{H}_{2} \mathrm{O}$ and $\mathrm{CO}_{2}$ strongly affect the phase relations of silicate melts at high pressures (Kushiro, 1969; Eggler, 1973). However, the following two lines of evidence eliminate the effect of volatile components in the formation of 707-D magmas:

1. The 707-D rocks are quite similar to magnesian MORB in terms of major, trace, and isotope compositions, which would imply that the volatile content in the magma is quite similar in MORB and 707-D magmas. Muenow et al. (1980) indicated that the $\mathrm{H}_{2} \mathrm{O}$ content in fresh and rather evolved MORB glasses is less than $1 \mathrm{wt} \%$. Thus, a primary MORB magma must contain much smaller amounts of $\mathrm{H}_{2} \mathrm{O}$. Such a small amount of $\mathrm{H}_{2} \mathrm{O}$ in a magma, if present, will not greatly affect the melting-phase relations.

2. The solubility of $\mathrm{CO}_{2}$ in a silicate melt is small at pressures of around $1.3 \mathrm{GPa}$. This implies a negligible role of $\mathrm{CO}_{2}$ in controlling the phase relations of 707-D basalts.

Therefore, it can be inferred from the present anhydrous experiments that the primary magma for 707-D basalts separated

Table 3. Sr-Nd isotope compositions.

\begin{tabular}{lccc}
\hline $\begin{array}{c}\text { Core, section, } \\
\text { interval }(\mathrm{cm})\end{array}$ & ${ }^{87} \mathrm{Sr} /{ }^{86} \mathrm{Sr}$ & ${ }^{143} \mathrm{Nd} /{ }^{144} \mathrm{Nd}$ & $\mathrm{ND}$ \\
\hline $115-715 \mathrm{~A}-29 \mathrm{R}-1,37-38$ & $0.703784 \pm 23$ & $0.513017 \pm 15$ & 7.51 \\
$115-706 \mathrm{C}-6 \mathrm{R}-1,48-50$ & $0.703985 \pm 15$ & $0.512920 \pm 21$ & 5.62 \\
$115-706 \mathrm{C}-9 \mathrm{R}-1,23-29$ & $0.703816 \pm 20$ & - & - \\
$115-707 \mathrm{C}-22 \mathrm{R}-1,94-98$ & $0.704489 \pm 19$ & $0.513117 \pm 20$ & 9.46 \\
$115-707 \mathrm{C}-27 \mathrm{R}-7,46-50$ & $0.703821 \pm 30$ & $0.513030 \pm 30$ & 7.76 \\
$115-713 \mathrm{~A}-13 \mathrm{R}-3,16-20$ & $0.703927 \pm 11$ & $0.512967 \pm 32$ & 6.54 \\
$115-713 \mathrm{~A}-20 \mathrm{R}-4,140-145$ & $0.704049 \pm 17$ & $0.512995 \pm 19$ & 7.08 \\
\hline
\end{tabular}

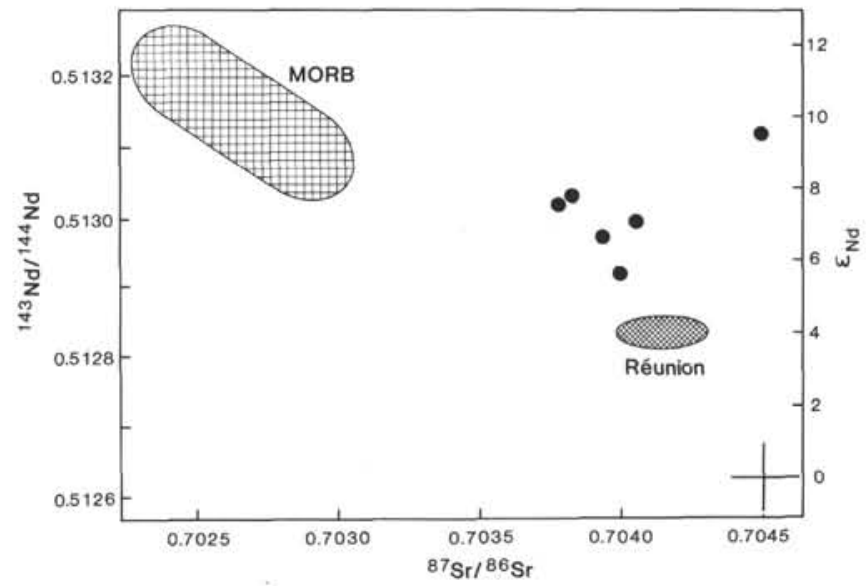

Figure 5. Nd-Sr isotope compositions for Leg 115 basement rocks. Data for N-MORB (DePaolo and Wasserburg, 1979) and Réunion rocks (Fisk et al., 1988) are also shown. $\epsilon_{\mathrm{Nd}}(0)$ for the present-day chondritic value is calculated to be 0.52632 by assuming that the La Jolla Nd standard $\left({ }^{143} \mathrm{Nd} /{ }^{144} \mathrm{Nd}=0.511855\right)$ corresponds to $\epsilon_{\mathrm{Nd}}=-15.15$ (Wasserburg et al., 1981).

from the upper mantle source at $1.3 \mathrm{GPa}$ and $1330^{\circ} \mathrm{C}$. Compared with the experimental results for magnesian MORBs (Fujii and Kushiro, 1977; Fujii and Bougault, 1983), the 707-D magma separated from the upper mantle source at a slightly higher pressure and temperature.

The melt composition of the RE464 basalt cannot coexist with orthopyroxene under dry conditions, indicating that the magma cannot be produced from the lherzolite source under such conditions. Furthermore, orthopyroxene is not the first phase to disappear in lherzolite minerals with increasing degrees of partial melting (Mysen and Kushiro, 1977). Thus, it is quite improbable that olivine and clinopyroxene are residual phases after the extraction of basalt magmas. On the other hand, the hypothesized primary magma for 706-E basalts can be in equilibrium with lherzolite minerals under $\mathrm{CO}_{2}$-saturated conditions. This is consistent with the idea that $\mathrm{CO}_{2}$ plays an important role in the formation of alkaline magmas (Wendlandt and Eggler, 1980). Also, alkaline magmas may contain small amounts of $\mathrm{H}_{2} \mathrm{O}$ to some extent.

Based on experiments conducted at high pressures (Tatsumi, 1982; Tatsumi et al., 1983), the addition of $\mathrm{H}_{2} \mathrm{O}(<3 \mathrm{wt} \%)$ to the basalt melt causes the shift of the point of multiple saturation toward lower temperatures and higher pressures without any change in phase relations. Therefore, the present experiments indicate the minimum pressure for the segregation of the basalt magma. As mentioned above, the RE464 basalt has a higher $\mathrm{FeO}^{*} / \mathrm{MgO}$ ratio than the calculated $707-\mathrm{D}$ primary magma. The possibility remains that the RE464 basalt is a derivative from a more magnesian, picritic primary magma. If this is the case, the primary magma must be more enriched in the olivine component than the RE464 basalt; such a magma can be produced at higher pressures and temperatures based on the experimental results of Takahashi and Kushiro (1983). It then follows that the pressure of multiple saturation given by the present experiments indicates the minimum depth of magma segregation. Consequently, the present experiments indicate that the 707-D tholeiitic magma was generated at shallower levels than the 706-E alkaline magma.

Because basaltic rocks belonging to chemical groups other than 706-E and 707-D show intermediate concentrations of incompatible elements, the primary magmas for these groups could have been produced at pressures around $1.5 \mathrm{GPa}$ (between 1.3 and $1.7 \mathrm{GPa}$ ). Basalts of $715-\mathrm{D}$ are the most magnesian among 
the intermediate groups (Fig. 2), and we have estimated the composition of a primary magma from the 715-D composition, based on the olivine maximum fractionation model. The results of this calculation are listed in Table 1 and are plotted onto the normative plane of plagioclase, olivine, and quartz, together with the calculated compositions of primary magmas for 707-D and 706-E (Fig. 6). Also plotted are the isobaric liquid composition trends obtained from the partial melting of a peridotite (Takahashi and Kushiro, 1983), which suggest that the primary basalt magmas for 715-D basalts separated from the upper mantle at pressures between those for 707-D and 706-E.

\section{Thermal Structure beneath the Hotspot}

It is widely accepted that primary magmas are segregated from mantle diapirs, rising from the deeper and hotter regions of the upper and/or lower mantle (Green and Ringwood, 1967; Cawthorn, 1975). Tatsumi et al. (1983) emphasized that the mantle diapirs rise until they are halted by the increase in viscosity of the surrounding upper mantle materials and magmas are released as a consequence. Because the viscosity of mantle material depends strongly on temperature, the depth of magma segregation or the depth at which diapiric uprise is strongly slowed can roughly indicate the position of an isothermal boundary in the upper mantle where viscosity changes rapidly. If this is the case, the geothermal gradient beneath the Réunion hotspot track was highest (shallower segregation) when 707-D basalts were formed and lowest (deeper segregation) for 706-E, Mauritius, and Réunion basalts (Fig. 7).

The oceanic lithosphere cools and thickens away from the spreading axis (Yoshii, 1975), suggesting that the geothermal gradient decreases off-ridge. The Réunion hotspot track is cut by an active ridge system (Fig. 1); the relative position between the ridge axis and the stable hotspot may have changed through Tertiary time. When the ridge axis was located close to the hotspot, the mantle diapir could rise to shallower levels, producing tholeiitic magmas like 707-D (Fig. 7). On the other hand, when the spreading axis was located far from the hotspot, such as the islands of Mauritius and Réunion, magmas would segregate from mantle diapir at deeper levels.

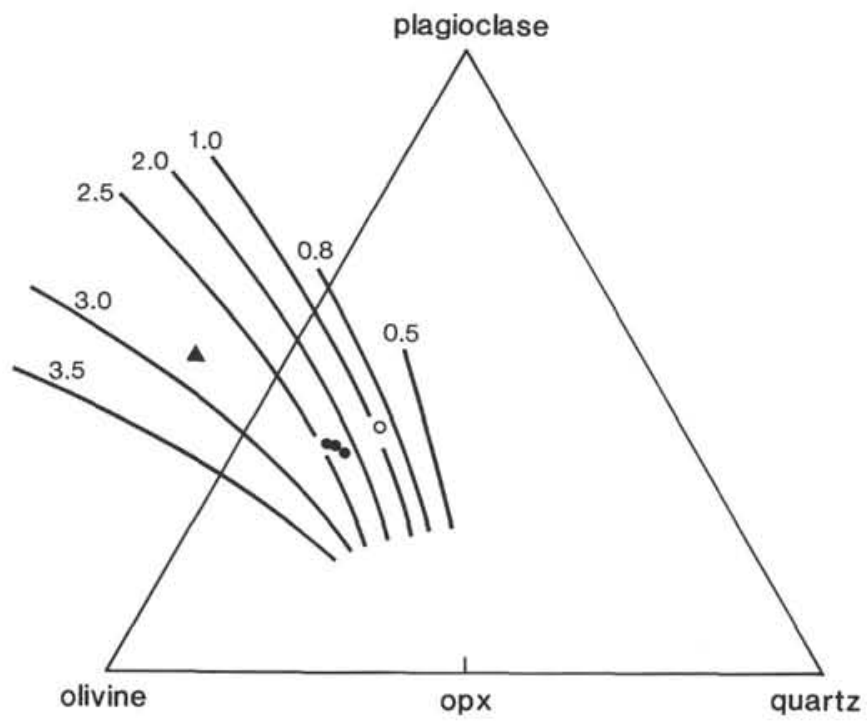

Figure 6. Normative compositions of primary magmas for 707-D (open circle), 706-E (triangle), and 715-D (filled circles) basalts in ternary projections by Walker et al. (1979). Isobaric liquid composition trends (solid lines with pressure in GPa) are after Takahashi and Kushiro (1983).

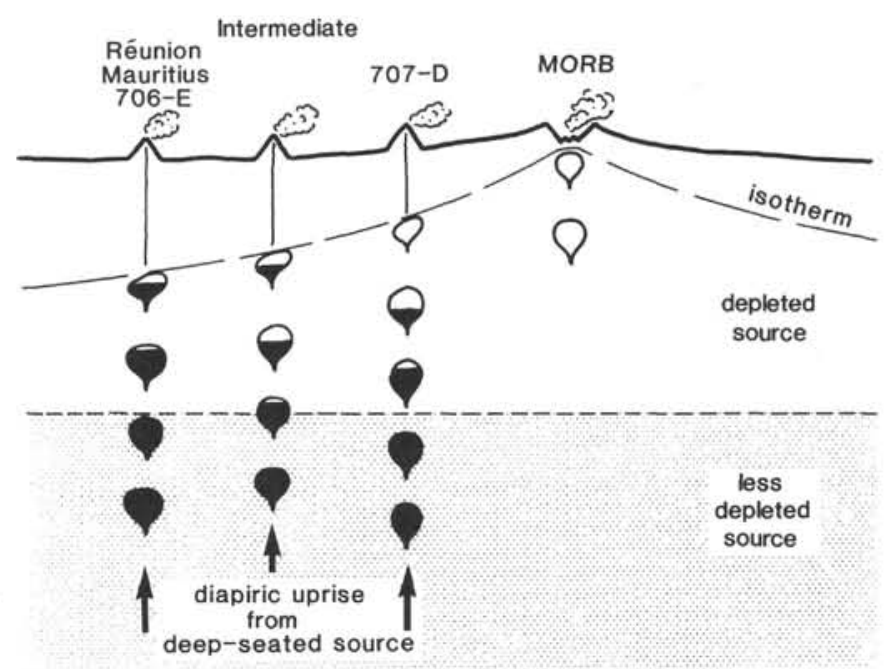

Figure 7. A cartoon for geochemical stratification in the upper mantle beneath the Indian Ocean. The location of each site is drawn relative to the spreading axis.

\section{Geochemical Stratification}

Through the process of diapiric uprise, materials in a diapir must interact physically and chemically with the surrounding mantle materials (Griffiths, 1986), indicating that the diapiric material varies its composition during its ascent. Thus, the chemical composition of a magma is partly controlled by the compositions of materials that are distributed along the path of diapiric uprise. Because the earth's mantle consists of at least two chemical domains, depleted and enriched, magmas originally derived from a deep-seated source like hotspot magmas may give information about the proposed two-layer chemical stratification in the mantle (DePaolo and Wasserburg, 1976) or more complex patterns of compositional heterogeneity. A magma that is segregated from a mantle diapir at a shallower level may contain a larger amount of the shallower geochemical component in the upper mantle.

The present experimental results, combined with the geochemical data, indicate that magmas that separate from a mantle diapir at a shallower level show more depleted geochemical characteristics in terms of both incompatible elements and $\mathrm{Sr}-\mathrm{Nd}$ isotope compositions. Furthermore, the chemical characteristics of such a depleted rock are similar to MORB. Therefore, our results are consistent with a simple layered mantle in which the depleted MORB source occupies the shallower part of the upper mantle and is underlain by more incompatible-element-enriched materials. Assuming that the less depleted material has $\mathrm{Sr}-\mathrm{Nd}$ isotopic compositions identical to the bulk earth (DePaolo and Wasserburg, 1976), the thickness of the depleted MORB source is greater than $60 \mathrm{~km}$, because the 706-E basalts are more depleted than the hypothetical bulk earth (Fig. 5). The 706-E basalt compositions are intermediate between bulk earth and depleted MORB sources, and their primary magmas segregated from a mantle diapir at pressures greater than $1.7 \mathrm{GPa}$ (around $60 \mathrm{~km})$. Within the intermediate chemical groups $(715,713$, 707-E, and 706-D in Fig. 2), the degree of source depletion as measured by isotopic composition is not always correlated with the degree of incompatible-element concentration. This may indicate the importance of magma mixing, small-scale mantle heterogeneity, and/or differences in the degree of partial melting of heterogeneous mantle (White et al., this volume). 


\section{REFERENCES}

Allégre, C. J., Hamelin, B., Provost, A., and Dupre, B., 1987. Topology in isotopic multispace and origin of mantle chemical heterogeneities. Earth Planet. Sci. Lett., 81:319-337.

Anderson, D. L., 1982. Isotopic evolution of the mantle: a model. Earth Planet. Sci. Lett., 57:1-12.

Backman, J., Duncan, R. A., et al., 1988. Proc. ODP, Init. Repts., 115: College Station, TX (Ocean Drilling Program).

Baxter, A. N., 1975. Petrology of the Older Series lavas from Mauritius, Indian Ocean. Geol. Soc. Am. Bull., 86:1449-1458.

Boyd, F. R., Bell, P. M., England, J. L., and Gilbert, M. C., 1962. Pressure measurement in single-stage apparatus. Year Book-Carnegie Inst. Washington, 65:410-414.

Boyd, F. R., and England, J. L., 1960. Apparatus for phase-equilibrium measurements at pressures up to 50 kilobars and temperatures up to $1750^{\circ} \mathrm{C}$. J. Geophys. Res., 65:741-748.

Boyd, F. R., and Nixon, P. H., 1975. Origin of the ultramafic nodules from some kimberiites of northern Lesotho and the Monastery Mine, South Africa. Phys. Chem. Earth, 9:431-451.

Cawthorn, R. G., 1975. Degree of melting in mantle diapirs, and the origin of ultramafic liquids. Earth Planet. Sci. Lett., 27:113-120.

DePaolo, D. J., and Wasserburg, G. J., 1976. Inferences about magma sources and mantle structure from variation of ${ }^{143} \mathrm{Nd} /{ }^{144} \mathrm{Nd}$. Geophys. Res. Lett., 3:743-746.

1979. Petrogenetic models and Nd-Sr isotopic patterns. Geochim. Cosmochim. Acta, 43:615-627.

Duncan, R. A., 1981. Hotspots in the southern oceans-an absolute frame of reference for motion of the Gondwana continents. Tectonophysics, 74:29-42.

Dziewonski, A. M., Hager, B. H., and O'Connell, R. J., 1977. Largescale heterogeneities in the lower mantle. J. Geophys. Res., 82:239255.

Eggler, D. H., 1973. Role of $\mathrm{CO}_{2}$ in melting process in the mantle. Yearbook-Carnegie Inst. Washington, 72:215-224.

Fisk, M. R., Upton, B.G.J., Ford, C. E., and White, W. M., 1988. Geochemical and experimental study of the genesis of magmas of Reunion Island, Indian Ocean. J. Geophys. Res., 93:4933-4950.

Fujii, T., and Bougault, H., 1983. Melting relations of a magnesian abyssal tholeiite and the origin of MORBs. Earth Planet. Sci. Lett., 62:283-295.

Fujii, T., and Kushiro, I., 1977. Melting relations and viscosity of an abyssal tholeiite. Yearbook-Carnegie Inst. Washington, 76:461-465.

Gast, P. W., 1968. Trace element fractionation and the origin of tholeiitic and alkaline magma types. Geochim. Cosmochim. Acta, 32: $1057-1086$.

Green, D. H., and Ringwood, A. E., 1967. The genesis of basaltic magmas. Contrib. Mineral. Petrol., 15:103-190.

Griffiths, R. W., 1986. Dynamics of mantle thermals with constant buoyancy or anomalous internal heating. Earth Planet. Sci. Lett., 78:435-446.

Jaques, A. L., and Green, D. H., 1980. Anhydrous melting of peridotite at $0-15 \mathrm{~kb}$ pressure and the genesis of the tholeiitic basalts. Contrib. Mineral. Petrol., 73:287-310.

Kushiro, I., 1969. The system forsterite-diopside-silica with and without water at high pressures. Am. J. Sci., Schairer Vol., 267A:269-294.
Mahoney, J. J., Natland, J. H., White, W. M., Poreda, R., Bloomer, S. H., Fisher, R. L., and Baxter, A. N., 1989. Isotopic and geochemical provinces of the western Indian Ocean spreading centers. J. Geophys. Res., 94:4033-4052.

Morgan, W. J., 1981. Hotspot tracks and the opening of the Atlantic and Indian oceans. In Emiliani, C. (Ed.) The Sea (Vol. 7): The Oceanic Lithosphere: New York (Wiley-Interscience), 443-487.

Muenow, D. W., Noiman, W.K.L., and Garcia, M. O., 1980. Volatiles in submarine volcanic rocks from the spreading axis of the East Scotia Sea back-arc basin. Earth Planet. Sci. Lett., 47:272-278.

Mysen, B. O., and Kushiro, I., 1977. Compositional variations of coexisting phases with degree of melting of peridotite in the upper mantle. Am. Mineral., 62:843-865.

Ringwood, A. E., 1970. Phase transformations and constitution of the mantle. Phys. Earth. Planet. Int., 3:109-155.

Roeder, P. L., and Emslie, R. F., 1970. Olivine-liquid equilibrium. Contrib. Mineral. Petrol., 29:275-289.

Silver, P. G., Carlson, R. W., and Olson, P., 1988. Deep slabs, geochemical heterogeneity, and the large-scale structure of mantle convection. Annu. Rev. Earth Planet. Sci., 16:477-541.

Takahashi, E., and Kushiro, I., 1983. Melting of a dry peridotite at high pressures and temperatures and basalt magma genesis. Am. Mineral., 68:859-879.

Tatsumi, Y., 1982. Origin of high-magnesian andesites in the Setouchi volcanic belt, southwest Japan. II. Melting-phase relations at high pressures. Earth Planet. Sci. Lett., 60:305-317.

Tatsumi, Y., and Ishizaka, K., 1982. High-magnesian andesite and basalt from Sho-Shima Island, southwest Japan, and their bearing on the genesis of calc-alkaline andesites. Lithos, 15:161-172.

Tatsumi, Y., Sakuyama, M., Fukuyama, H., and Kushiro, I., 1983. Generation of arc basalt magmas and thermal structure of the mantle wedge in subduction zones. J. Geophys. Res., 88:5815-5825.

Walker, D., Shibata, T., and DeLong, S. E., 1979. Abyssal tholeiite from Oceanographer Fracture Zone. 11. Phase equilibria and mixing. Contrib. Mineral. Petrol., 70:111-125.

Wasserburg, G. J., Jacobsen, S. B., DePaolo, D. J., McColloch, M., and Wen, T., 1981. Precise determination of Sm/Nd ratios, Sm and Nd isotopic abundances in standard solutions. Geochim. Cosmochim. Acta, 45:2311-2323.

Wendlandt, R. F., and Eggler, D. H., 1980. The origin of potassic magmas: 1 . melting relations in the system $\mathrm{KAlSiO}_{4}-\mathrm{Mg}_{2} \mathrm{SiO}_{4}-\mathrm{SiO}_{2}$ and $\mathrm{KAISiO}_{4}-\mathrm{MgO}-\mathrm{SiO}_{2}-\mathrm{CO}_{2}$ to 30 kilobars. Am. J. Sci., 280:385-420.

White, W. M., 1985. Source of oceanic basalts: radiogenic isotope evidence. Geology, 13:115-118.

Wyllie, P. J., 1988. Magma genesis, plate tectonics, and chemical differentiation of the Earth. Rev. Geophys., 26:370-404.

Yoshii, T., 1975. Regionality of group velocities of Rayleigh waves in the Pacific and thickening of the plate. Earth Planet. Sci. Lett., 25:305312.

Zindler, A., and Hart, S., 1986. Chemical geodynamics. Annu. Rev. Earth Planet. Sci., 14:493-571.

Date of initial receipt: 3 February 1989

Date of acceptance: 16 November 1989

Ms 115B-136 